\title{
Rural transformation, network society and the information age: The case of Nkonkobe District Municipality in the Eastern Cape
}

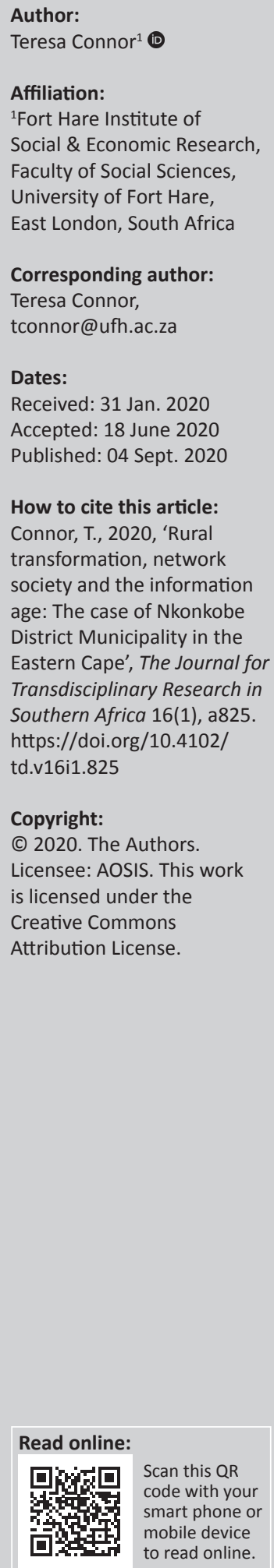

\begin{abstract}
The aim of this article is exploratory: to illustrate the main trends in communication and amongst data users in the Nkonkobe Municipal Area, a municipal zone in the Eastern Cape Province of South Africa, now known as Chris Hani. Based on information collected in 2016 and 2017, the research project locates the use of both cellular phones and smartphones within a broader menu of communication devices and information retrieval in rural areas, including televisions, radios, newspapers and conventional interaction. It focuses particularly on the conditions and circumstances under which cellular phones and smartphones were used and the type of residents who were most likely to use them. Many analysts are of the opinion that cellular devices can increase communication in economically disadvantaged zones through the creation of a shared 'virtual social network' that 'levels' society, creating equal access to information. The results of this study reveal that although smartphones are widespread, these types of devices have not replaced communication via cellular phones or physical interaction. Realistically, smartphone usage is limited by cost and network coverage. For the majority of smartphone owners, connectivity is not always easy and compels movement towards regional urban centres, where data is cheaper and can be accessed.
\end{abstract}

Keywords: Communication; Smartphones; Networks; Rural areas; Eastern Cape.

\section{Introduction}

Since the end of apartheid, there has been little focus on the connections between rural residents within the former homelands. Moreover, there has been little written on the changing nature of small rural towns and the role that they may play in rural development. After the Marikana massacre, as Bank (2015:1068) points out, it became clear that many migrants were still investing in rural areas. The formations of these rural investments, however, have changed. Firstly, widespread deagrarianisation and climate change in the Eastern Cape have increased circular migration to small towns, particularly by the youth and within the informal sector (Connor \& Mtwana 2018). Secondly, many investments made in rural areas are sometimes undetected because they are based on smaller financial packages - such as pensions and social grants (Mishi et al. 2020). Rural areas have therefore seen increased investment into cultures of mobility and largely unseen networks that do not always require long-distance migration or actual physical movement. As Klaufus (2012:691) argued, the connections between global flows of people and goods demonstrate that 'agency can be activated through both geographical movement and through imagined connections ... across space, even when they are relatively immobile'. In rural areas symbolic mobility and investment have occurred around the home space, where construction of houses, the purchase of domestic appliances and the reliance on cellular phones have influenced levels of access to information and resources (Ruiters 2011).

The National Census of 2011 (Statistics South Africa [Stats SA] 2011) shows that rural areas in South Africa have had a 50\% increase in the use of cellular devices from 2001. This includes a rapid expansion of cellular $3 \mathrm{G}$ networks and the use of Internet smartphones. The transformational capabilities of the mobile phone are therefore very important for rural residents because, according to Van Dijk (2005) and Castells (1996), these devices not only enable access to previously untapped resources but may serve as virtual social connections - the 'glue' that holds society together. However, it is matter of debate whether these virtual device connections take place at a suprasocietal level, independent of real-time connections, or whether cybernetic conversations replace

Note: Special Collection: Mobile Technology within the 4IR era - Africa answering the call. 
standard interactions between people (De Bruijn 2008:5). Although it cannot be disputed that handheld communication devices have proved powerful in the creation of a 'virtual social network' that connects previously disparate people and places to share information and opportunities, it still has to be determined whether smartphones have the ability to 'level' society (Castells 1996). Can virtual handheld devices reduce differences of income, gender and age?

In order to assess these issues, this article illustrates the main trends in communication and amongst data users in the Nkonkobe Municipal Area. As illustrated in Map 1, this is a rural municipal zone in the Eastern Cape Province of South Africa, now known as Chris Hani. Based on information collected in 2016 and 2017 (FHISER 2017), this article locates the use of mobile phones within a broader menu of communication devices and information retrieval in rural areas. The question is whether these devices have replaced the use of televisions, radios, newspapers and conventional interaction and whether all residents use devices in the same manner. Ultimately, the article aims to assess how and whether these devices have improved service delivery and whether the Internet has indeed resulted in poverty alleviation. The article has four sections: the first is largely theoretical and evaluates the idea of the 'network society', comparing it to what is known as the 'information age'. The second section discusses methodology, whilst the third provides a regional background to the study. The results are discussed in three portions:

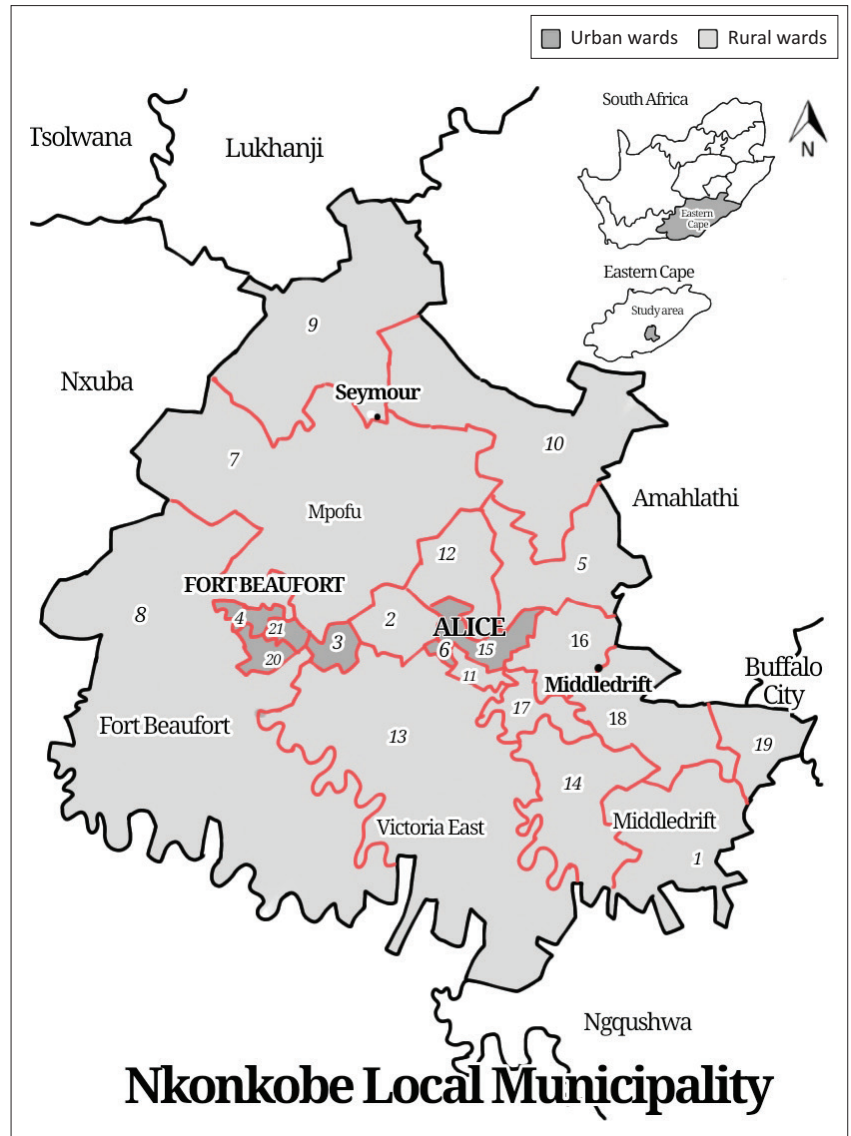

MAP 1: Nkonkobe Local Municipality with ward boundaries.
- the basic profile of respondents in Nkonkobe and use of devices and means of communication

- the use of cellular devices in Nkonkobe, including smartphones

- communication with government and stakeholders in Nkonkobe.

\section{Theoretical background: Social networks}

Social networks have traditionally been treated as the linkages that keep people, social institutions and groups 'bound together'. As Mitchell (1974:283) originally argued, social networks are regarded as complex and multistranded relationships within which various bonds of exchange and obligation are at play. Within the context of exchange, social networks rely on a mutual exchange of information, a reciprocal give and take, that enables people to engage in financial, social and cultural transactions. These exchanges promote the longevity and vitality of society because they are based on mutual forms of communication and information sharing. This means that the use of electronic devices is not simply about managing information, nor is it solely linked to the amount of information that can be retrieved from outside sources. Social networks, more than information, influence how people respond politically and culturally, based on the extent to which they connect to one another (Mitchell 1974:280).

It is this 'network society', as Castells has coined it (1996), rather than an 'information society', that functions as the 'nerve centre' of virtual social and media networks that shape organisational structures and processes. Although mobile devices can change the form of standardised local information by providing access to global issues, only social networks can create greater access to locally valued and contextualised information. The debate, therefore, is whether content provided by information and communications technology services in poorer communities enables people to speak for themselves (Cecchini \& Scott 2003) or whether information is simply presented for consumption. As Castells (1996) points out, real power is to be found more within these networks than within regional urban spaces.

There are clearly some pertinent questions that must be asked about the impact of mobile technologies on rural populations. One of the first issues that must be addressed, as De Bruijn and Van Dijk (2012) suggest, is differences in the quality and speed of the Internet, as well as dissimilarities in the gender, age and income of the user. These differences may prevent people from accessing information and opportunities and reduce the ability of policymakers and municipal officials to communicate effectively. In South Africa, where racial and class divisions persist, there are clear differences between resource allocation in rural and urban areas. There are also relatively new divisions that have emerged between unemployed youth and their relatively well-off pensioned elders, as well as between established rural residents and immigrants to small towns. Thirdly, there are also disparities 
between virtual mobile networks and more traditional physical forms of networking that influence information consumption, communication and access to global information. The question is how do these levels of inequality affect the use of the Internet and of smartphones? What forms of information and communication do people use in order to gain the most visibility?

\section{Methodology}

Grounded on these primary research questions, the approach of the project team was exploratory: to determine the various types (or channels) of communication in Nkonkobe Municipality, how they were used and whether they were effective in increasing communication between residents and with policymakers. In order to understand this, the first step was to analyse secondary information regarding the development of rural areas in the Eastern Cape, paying particular attention to the development of small towns and urban hubs.

Secondly, a survey was designed based on the basic profile information of the region and the municipality, which provided a baseline for the research in Nkonkobe. Regional information garnered from Census 2011 (Stats SA 2011) reflects that the population in the Eastern Cape is around 6.8 million, an increase of 5 million since $2001 .{ }^{1}$ Approximately 850000 households live in rural areas, and within these, another 700000 are found within urban or peri-urban areas. The General Household Survey in 2016 established that $51.60 \%$ of inhabitants in the Eastern Cape lived in rural areas.

Given that Nkonkobe has been dissolved, at the time of data collection in 2016, Nkonkobe had a population of 27716 households, or 135660 individuals (Nkonkobe IDP 2011). As Map 1 illustrates, the district was divided into 21 wards and 5 small towns, these being (in order of size) Fort Beaufort (7379 households), the university town of Alice (3716), Seymour (864), Middledrift (453) and the mountain village of Hogsback (344). According to Census 2011, 39.9\% of households in Nkonkobe were urban, whilst $60.1 \%$ were rural and farm based. Five of these wards were classified by Stats SA (in Census 2011) as being predominantly urban, whilst another two wards were classified as being partially urban. Approximately $74 \%$ of households were classified as indigent, and the dominant age bracket in the municipal areas was between 25 and 35. The largest wards in Nkonkobe are 9, 6, 15, 13, 14 and 2. As Map 1 indicates, urban wards are predominantly clustered around the towns of Alice and Fort Beaufort.

As a baseline, the survey sample had to include at least $10 \%$ of the total population - this being 127 people - of which we managed to interview 121. We also captured information from 13 wards in Nkonkobe, not 21. This can be attributed to the fact that wards in Nkonkobe overlap considerably.
The area around and within the town of Alice, for example, consists of four overlapping wards - this being the city centre (Ward 6), the University of Fort Hare campus (Ward 11) and two other predominantly rural wards (2 and 15). The fieldworkers concentrated on the campus area (Ward 11) and Ward 2, which all contain residents and people who live and work in the Alice area.

Moreover, in our sample, around 56\% of respondents were from urban zones and $44 \%$ from rural areas, which disagrees with the overall classification of Nkonkobe as $60.1 \%$ rural. This is largely because many wards are classified as mixed urban and rural zones, with a dominance of one, and are therefore more peri-urban or semi-rural than strictly one or the other. Moreover, although the fieldworkers did survey rural areas, some rural residents were interviewed in an urban zone and were therefore classified as being 'urban'. The proportion of rural to urban residents is therefore approximate.

The methodology used was a mixture of qualitative and quantitative techniques, as well as the principles and selected methods derived from participatory rural appraisal (PRA). Developed by Chambers (1994), PRA uses a multidisciplinary approach for applied research and is particularly effective for learning about local-level conditions and perspectives in a relatively short period of time. A portion of the PRA approach is about ensuring local buy-in and endorsement of a research project. Consequently, the research team spent eight months during early 2016 negotiating access to local communities via local government representatives and counsellors in Nkonkobe. During this period permission from the town council was obtained, and we attended two local council meetings in order to introduce the project to local officials. This was followed by three community forum meetings in rural areas, and another two in the town of Alice. These meetings also enabled the selection and training of eight local unemployed youth from a local non-governmental organisation (NGO) as fieldworkers, in order to administer questionnaires and collect information. This initial phase of data collection provided the comparative underpinnings of the project as a whole, particularly the differences between peri-urban and rural zones in Nkonkobe, as well as the influence of both NGOs and state-driven structures. This was the basis for our focus on qualitative information for the project, which also used observations and interviews in rural villages, as well as three group sessions held with stakeholders in Alice during February 2016. These included various NGOs, community-based organisations (CBOs) and other affected groups (including residents' associations), as well as municipal and provincial role players. ${ }^{2}$

\section{Regional background: Profile of the Eastern Cape and Nkonkobe}

Analysis of the literature and secondary data reveals that the province of the Eastern Cape is one of the most severely

2.The author thanks World Vision in Middledrift for use of their premises and for sourcing local fieldworkers, as well as the Deutsche Gesellschaft für Internationale sourcing local fieldworkers, as well as the Deutsche Gesellschaft für Internationale
Zusammenarbeit (German Development Corporation or GTZ) for providing Zusammenarbeit (German Development Corporation or GT
introductions to local councilors and policymakers in Nkonkobe. 
deagrarianised ones in southern Africa. Self-sufficient peasant farming has largely disappeared, and commercial production of crops is subsidised heavily by the state (Connor \& Mtwana 2018). After decades of large-scale migration, fuelled by the labour needs of mines and industry, income in the province has shrunk. The General Household Survey in 2016 points out that $55.92 \%$ of households in the Eastern Cape earn money from transfer or non-earned income pensions, state grants and remittances - whilst very few $(0.17 \%)$ are engaged in farming as a main activity.

Services such as roads, electricity and water in many areas are absent or hampered by ineffectual policies and corruption (Ruiters 2011), whilst a crippling drought during the last three years has sapped the resources of rural households. Compared to urban areas such as Buffalo City (East London) and Nelson Mandela (Port Elizabeth), rural households have only half the amount of basic services available to them (Rogan 2018). Moreover, cellular 4G network coverage is limited to urban zones and the roads linking them, whilst 3G coverage is almost $99 \%$.

However, not all of the changes in the Eastern Cape have been negative. As Bank's work has indicated (2015), migration in the Eastern Cape has shifted away from distant labour migration opportunities in mines and large urban zones towards expansion of the small housing market and small businesses in rural towns. This has transformed many rural towns into business and residential hubs because of expansion of the informal sector, where people are able to access livelihood resources fairly easily, and where smaller state grants and pensions can be spent. Moreover, the fact that almost $40 \%$ of Nkonkobe is classified as being urban works in the favour of people and businesses who seek new ways of communicating and connecting with the public. This is in comparison to some overtly rural areas in the province, such as the Intsika Yethu Local Municipality in Cofimvaba, where a ward-based resource audit was conducted in 2013 (Connor 2013). Here it was found that only $3 \%$ of people live in urban areas and that rural areas are severely isolated and underdeveloped.

In fact, scholars have noted a decline in the classification and treatment of rural and urban areas (Donaldson \& Marais 2012; eds. Marais, Nel \& Donaldson 2016) and have noted that the differences between them might not be as disparate as originally thought. In many respects, rural and urban zones are similar, not only because of the social and economic ties with large cities but because of changes within rural hinterlands themselves. In censuses, rural and urban areas are usually defined by size - a population density of 500 people or more per square kilometre, parallel or grid-like street patterns, and the presence of public buildings such as parks, cemeteries or libraries are indications of urbanity. Agriculture is generally assumed to be the principal activity of rural dwellers, whilst urbanites are thought to engage in industrial activities.
However, in reality things are much more complex. Rural residents in Nkonkobe do not primarily engage in agricultural activities, but use a cash income as their livelihood basis. Towns such as Alice and Fort Beaufort also do possess a relatively high population density and other urban indicators such as libraries and parks. Conversely, it is also true that urban areas in Nkonkobe are also partially rural because many people still own and use rural resources (such as stock) and invest in rural homes. Moreover, population movement and migration, particularly from rural areas to towns such as Alice and Fort Beaufort, are usually not reflected in census data, which makes the idea of 'discrete units' of rural and urban residents unreliable.

Analysts have pointed out that many larger, centrally placed small towns in South Africa have grown economically, supplying the retail and servicing needs of a larger hinterland in an era of improved transportation and the economic decline of smaller settlements in their hinterlands. These spaces are closer to urban centres, suggesting improved spatial access. Harrison and Todes $(2015: 153,155)$ argue that individuals and households in South Africa are 'voting with their feet' by moving into places that are better able to provide livelihoods.

Nkonkobe is a particularly good example of this because of the growth experienced by educational centres such as Alice, where accommodation for students is in great demand (FHISER 2011) and where civil service employment and infrastructure in towns such as Middledrift and Fort Beaufort has expanded. The reclassification of communal land surrounding Alice to urban status cannot take place fast enough, and housing and basic services are under pressure. In fact, Alice has more potential for a niche housing market than any other small towns in the province because it has a secure employment base of educators, civil servants and student population, as well as a fair amount of tourist thoroughfare.

Thus, whilst it may still be true that economic migration to distant urban centres such as Johannesburg and Cape Town have and will continue to occur, the Eastern Cape tends to support circular migration more than permanent migration to urban areas. Circular migration involves temporary relocations to nearby urban zones and a periodic return to a rural home base. For some individuals this trek may be only a few kilometres, whilst for others it may be long term and require more distant mobility. Rural households in Nkonkobe are thus well connected to urban zones, and whilst they are not always well resourced, they are considerably better off than many other predominantly rural districts in the province. Nkonkobe is therefore in a better position to receive and handle virtual information and support smart social networks.

\section{Ethical considerations}

This article followed all ethical standards for research without direct contact with human or animal subjects. 


\section{Results}

\section{The use of information and communication devices}

Nkonkobe has a demographic profile that is dominated by young, single and educated individuals, with a high proportion of students and professional employees. The town of Alice serves as a hub for students attending the University of Fort Hare and Lovedale College. Thus, around 43\% (52 respondents) were from rural areas. Age-wise, 63\% of the respondents in this study were between the ages of 20 and 40 - a relatively higher proportion than is generally found in the province. Just over $4 \%$ of our respondents were over the age of 61 years, with another $25 \%$ between 41 and 60 years of age. With regard to education, most respondents had matriculated or had a higher qualification $-29 \%$ possessed a university or college education, whilst $32 \%$ had actually matriculated. Almost 35\% of respondents said that they were unemployed, whilst 17\% (32 individuals) indicated that they were civil servants working for the local municipality.

The degree to which technology and consumer goods inform the development of households is a trend that is reflected positively in Census 2011. Households in Eastern Cape are becoming more modernised through the possession of electronic items such as televisions and phones, supported by the rapid expansion of the electricity grid in rural areas of South Africa. Power provision in Nkonkobe in 2017 was around $76 \%$, as reflected in the Integrated Development Plan ([IDP] 2012-2017), this being 21159 out of 27716 households.
As seen in Figure 1, televisions were the most commonly owned communication devices found in Nkonkobe, almost $87 \%$. This is followed by radios, which $76 \%$ of people owned, followed closely by smartphones (75\%). Almost $48 \%$ of households had access to or read a newspaper on a regular basis, whilst $44 \%$ had satellite television installed and thus have access to satellite television. Magazines are last on the priority of most household items; they were only read by $34 \%$ of the sample. Only $18 \%$ people had access to a personal computer at home. When compared to the Census 2011 results, the ownership of personal computers (PCs) in Nkonkobe was very much the same - just over $16 \%$ of households had access to a computer (Stats SA 2011).

A comparison of radio and television listenership with factors such as age, gender and education is not very useful because both devices are very popular across all categories. However, unlike cell phones, radios, televisions and newspapers do not enable two-way communication and are mostly used for entertainment purposes by our respondents. Cellular phones are the only devices that work on communication between two different individuals, and for this reason they are invaluable.

As Census 2011 indicates in Table 1, the proportion of households using cell phones in the Eastern Cape has increased exponentially in the decade since 2001, by almost $60 \%$. This is immensely important for rural areas such as Nkonkobe because in principle cell phone data are relatively cheap and can be purchased in smaller amounts in order to

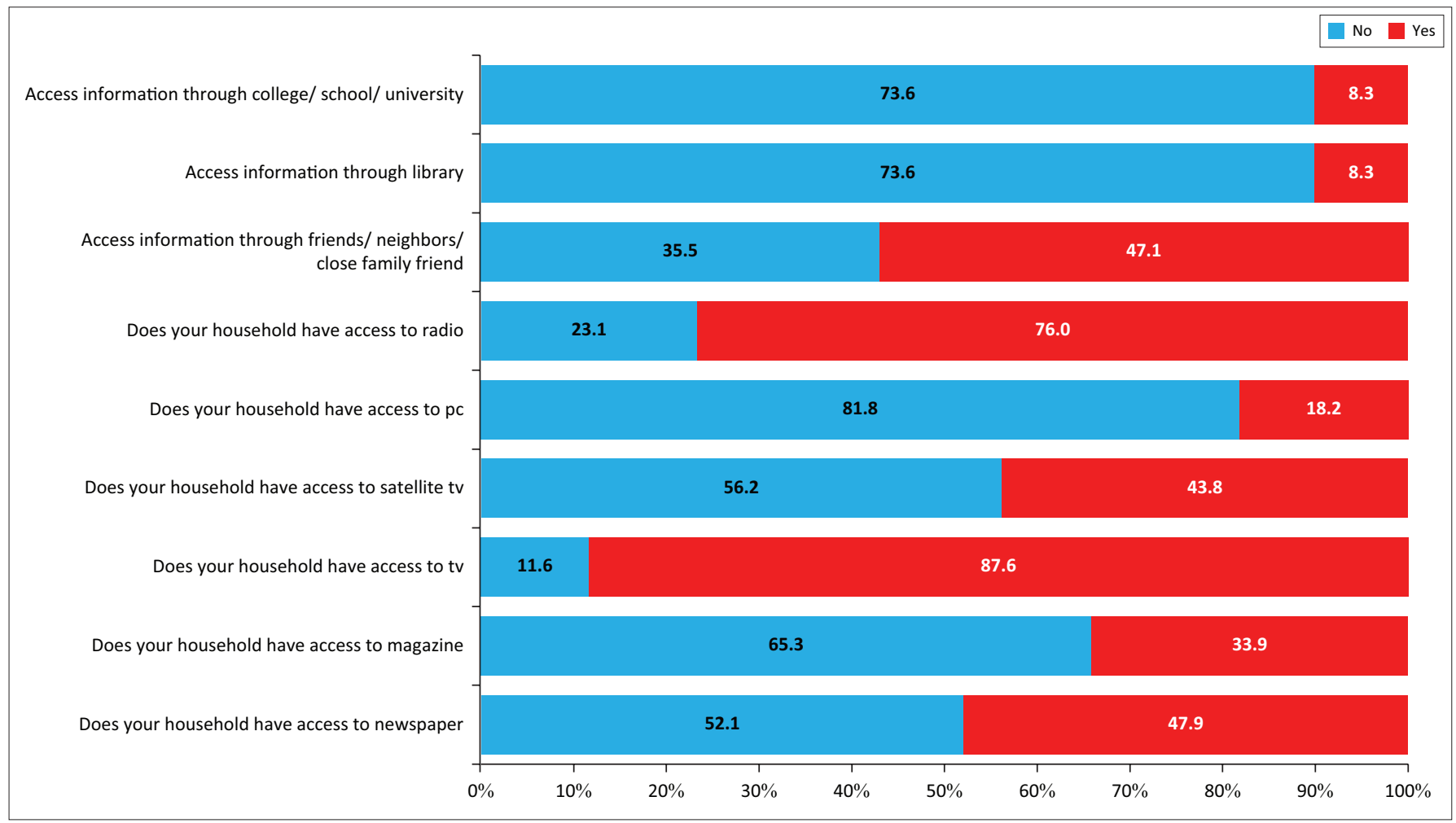

Source: Nkonkobe Local Municipality, 2011, 'Integrated Development Plan 2012-2017', Government Printers, Nkonkobe.

PC, personal computer; TV, television.

FIGURE 1: Household access to information and communication devices. 
create a fast and effective means of communicating between individuals. As our initial data illustrate in Nkonkobe, the ownership of smartphones (that are able to access the Internet) is high, almost $75 \%$.

As Figure 2 depicts, the majority of respondents in the sample $(75 \%)$ possessed a smartphone (a device that can access the Internet), whilst 32\% used basic cell phones that had text (SMS) and phone call function. It seems that the majority $(60 \%)$ of those who owned basic cell phones were elderly, over the age of 60 years. Comparably, just over $88 \%$ of people who owned smartphones were from a younger age group, between the ages of 20 and 30. It must be said that basic cell phones were not very popular, and smartphones were distributed relatively well over all the age groups in our sample, with the possible exception of those over 60 .

When smartphone ownership is compared to occupation, it seems that housewives and unemployed individuals had the least access to smartphones, whilst civil servants had the most access, followed by students and business employees. When compared to individual information, the number of those who had access to any cellular device in a household was even higher, over $98 \%$. Another 73 people indicated that there were between one and three people who owned a phone in their household. There were only two households that did not have access to any type of cell phone at all.

Despite the high number of Internet-capable cell phones, the data from Census 2011 do not make a distinction between smartphones and regular cellular devices. As indicated in
Table 1, census information just states that $81 \%$ of people in Nkonkobe do not have access to the Internet and that of the total population, $12 \%$ used cell phones to access the Internet. The figures collected from the respondents in Nkonkobe for this survey were much higher - amongst the 113 responses received, $84 \%$ used their phones to access the Internet, whilst $10 \%$ used PCs.

It is interesting that the respondents did not always associate Internet access with smartphones but with the installation of a fixed line or broadband connection via a telephone line or fibre. Only 27 people indicated that they did have such a connection; the vast majority (79\%) did not. Moreover, Internet access also seems to be age related. Those who used the Internet the most were aged between 20 and 30 years of age, this being $40 \%$ of our sample, followed by $31-40$ year olds (28\%) and $41-50$ year olds $(15.7 \%)$. It thus seems (predictably) that access to the Internet declines with age. Thus, the majority of individuals who have access to the Internet are located in towns and are students, educators or civil servants. In fact, many individuals from outlying rural areas travel to towns like Alice precisely because they can purchase data packages or use free Wi-Fi at work on campus.

\section{The use of cellular devices and access to the Internet in Nkonkobe}

The use of the Internet in South Africa is influenced by various factors. The first is network capability - and here, it seems that the two main cell phone network providers in South Africa deliver excellent 3G coverage of the Nkonkobe

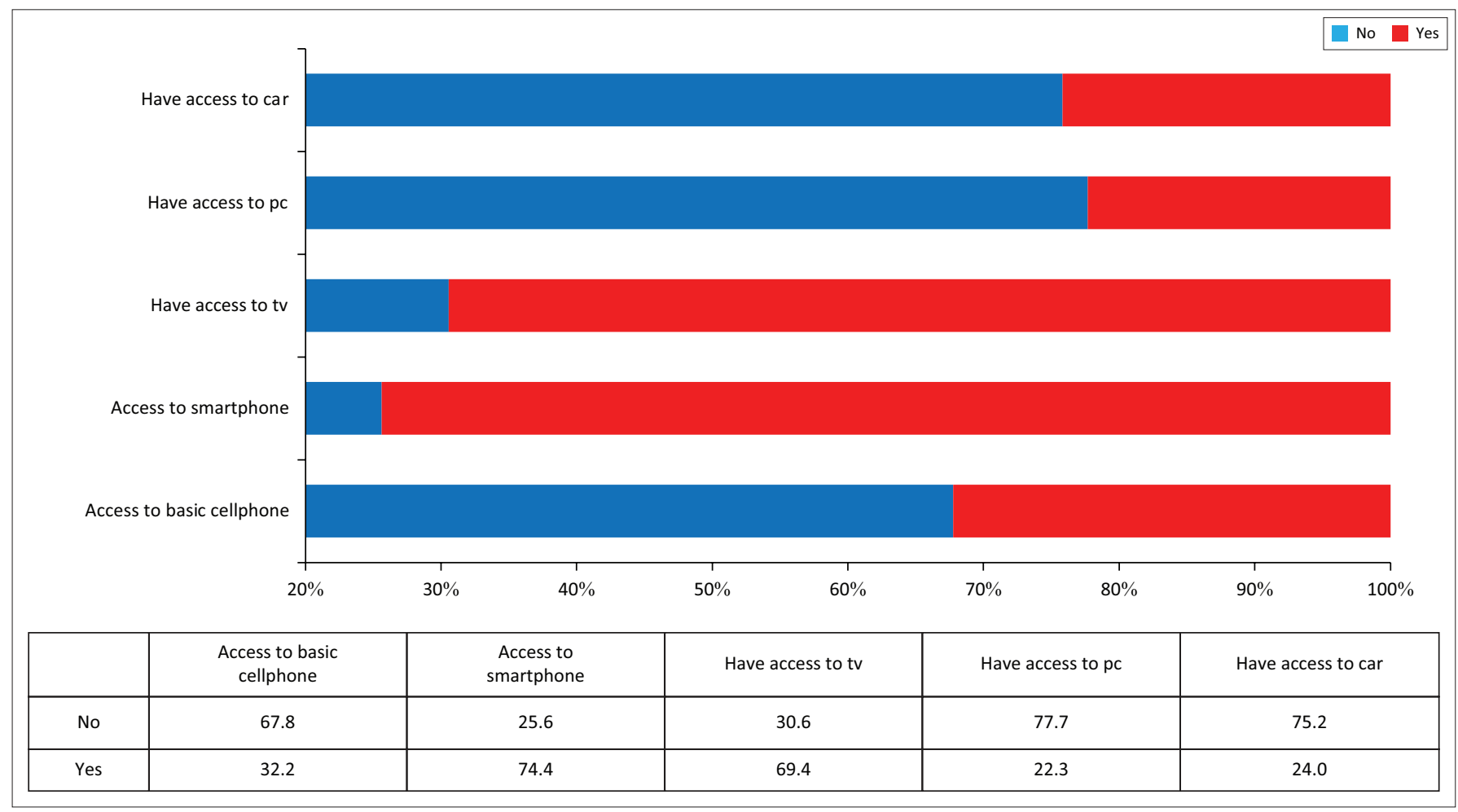

Source: Nkonkobe Local Municipality, 2011, 'Integrated Development Plan 2012-2017', Government Printers, Nkonkobe.

$\mathrm{PC}$, personal computer; TV, television.

FIGURE 2: Access to cars, radios, televisions and phones. 
TABLE 1: Access to the Internet in Nkonkobe (Census 2011).

\begin{tabular}{|c|c|c|c|c|c|c|c|c|}
\hline \multirow[t]{2}{*}{ No. of people who access the Internet } & \multirow[t]{2}{*}{ Seymour } & \multirow[t]{2}{*}{ Hogsback } & \multirow[t]{2}{*}{ Middledrift } & \multirow[t]{2}{*}{ Fort Beaufort } & \multirow[t]{2}{*}{ Alice } & \multirow[t]{2}{*}{ Other } & \multicolumn{2}{|c|}{ Nkonkobe } \\
\hline & & & & & & & $n$ & $\%$ \\
\hline From home & 3 & 68 & 14 & 305 & 123 & 351 & 742 & 2 \\
\hline From work & 13 & 28 & 29 & 236 & 304 & 476 & 783 & 2.3 \\
\hline From elsewhere & 4 & 8 & 10 & 248 & 254 & 599 & 870 & 2.6 \\
\hline No access to Internet & 760 & 195 & 348 & 5540 & 2543 & 21800 & 28641 & 81 \\
\hline Total & 865 & 343 & 453 & 7379 & 3716 & 26315 & 35355 & - \\
\hline
\end{tabular}

Source: Statistics South Africa, 2011, 'Census 2011', viewed 07 May 2020, from https://www.statssa.gov.za/publications/P03014/P030142011.pdf.

region, between $95 \%$ and $98 \%$. This type of connection supports calls, texts, web browsing, email, apps, video streaming and file downloads. LTE, a super high-speed connection, is only available around the main towns and highways in the region. Fibre and fixed-line access to the Internet is relatively rare in Nkonkobe, being limited to those businesses and individuals who can afford this expense, and is widely used in central areas such as Alice, Fort Beaufort and Hogsback. The extent of cellular coverage in Nkonkobe was corroborated by the respondents, who indicated that they could and did access the Internet, with the exception of wards 2, 3, 9, 4 and 11. In these wards, approximately $20 \%$ of people could not access the Internet because they were located in remote and mountainous terrain, with patchy cell phone coverage.

However, Internet access is also influenced by the price of data and airtime for cell phone users, as indicated in Table 2. In Nkonkobe, it is clear that users who have a cell phone contract, and do not have to buy airtime, are more likely to download and use data than those who are on a prepaid plan. The majority of our respondents (104 people, or 86\%) used prepaid data, whilst only 15 individuals were on contract. Prepaid costs are thought to be relatively high in South Africa, which makes it difficult to perform tasks such as transferring files or watch YouTube without being tethered to a Wi-Fi connection. Moreover, access to broadband is a luxury in Nkonkobe that is not always possible, making data packages the only option, which can be far more expensive on a per-gigabyte basis than on contract. The price of one gigabyte of data in South Africa was estimated in June 2019 to be R106.20, just one place higher than Germany and in 10th place after India (R3.84) and Russia (R13.44). ${ }^{3}$

The amount spent by our respondents on data bundles in Nkonkobe was relatively high. Around $40 \%$ of our respondents spent R50 per week or more on connectivity, whilst $17 \%$ spent below R20 per week. The majority of people - this being 49\% - spent between R21 and R50 per week on the Internet. This is fairly high compared to low income levels amongst households in the province; Westaway (2012:116) estimated that rural households earned far less than urban households (R1276 compared to R2357) and that $73 \%$ of rural people in the Eastern Cape were living on less than R300 per month in 2005-2006.

3.https://mybroadband.co.za/news/cellular/309693-mobile-data-prices-southafrica-vs-the-world.html (accessed 28 January 2020).
TABLE 2: Money spent per week by percentage of population on Internet bundles and airtime.

\begin{tabular}{lcc}
\hline Amount & Internet data (\%) & Airtime (\%) \\
\hline R0-R5 & 11.6 & 1.7 \\
R5-R10 & 14.9 & 12.4 \\
R10-R15 & 20.7 & 15.7 \\
R15-R20 & 20.7 & 16.5 \\
R20 or more & 30.6 & 52.9 \\
\hline
\end{tabular}

Source: Nkonkobe Local Municipality, 2011, 'Integrated Development Plan 2012-2017', Government Printers, Nkonkobe.

With regard to the amount of money spent on airtime and data, the amount of money spent by individuals on airtime does outstrip the purchase of Internet data by about $20 \%$. However, it is notable that most people spent over R20 per week on both airtime and Internet, and this indicates the willingness of people to invest into their social network and ability to communicate with their devices. The use of airtime means that people are more likely to prefer speaking directly to one another than simply using Short Message Service (SMS) or WhatsApp messages.

One of the consequences of the high cost of connectivity in the rural areas of Nkonkobe is that it reduces the efficacy of cell phone use and good network coverage in the region and compels people to move towards urban centres in order to purchase data and access free broadband. Ramburn and Van Belle (2011) confirm this and cite the impact of cost as both a determinant and inhibitor of mobile data services, which is not often given prominence in research within developed countries. The high cost of prepaid cellular data, as well as lack of coverage in rural areas, thus prevent residents in Nkonkobe from using the Internet as effectively as their urban counterparts in regional cities, such as Port Elizabeth and East London. Instead, people mainly use cellular devices to make phone calls and send SMS messages. When respondents were asked which applications they preferred to use on their cell phones, the most preferred application was SMS or text messages, followed by Facebook and WhatsApp. Most respondents (32\%) indicated that they 'never used' WhatsApp, and only two people said that they used this application 'often'. Another two people used Twitter, and the same amount used Tango. Facebook was used 'often' by 21 people in our sample. This was a surprising find, especially because WhatsApp, Twitter and Mxit have very low data costs and are widely used by urban youth in South Africa. WhatsApp in particular is the most widely used app in Africa, and in 
Zimbabwe it was responsible for about half of all Internet data in $2018 .^{4}$

The discrepancy between smartphone ownership and Internet usage emerged most clearly during this survey and was supported by the low numbers of people in rural wards who used free data based applications such as WhatsApp. WhatsApp is widely known to offer benefits such as cost, a sense of community and immediacy, whilst SMS is generally more expensive - although it is regarded as a more reliable and privacy preserving (Church \& De Oliveira 2013:352). This was also the finding of Ramburn and Van Belle (2011), who mention that users in their case study in Mauritius were slow to adopt 3G data services and that people were reluctant to engage in other mobile data services, such as web browsing and the use of free apps. Users cited increased costs, possible leakage of personal information and spamming as the most prominent factors that inhibited their use of data. This was a pattern echoed in Nkonkobe and is driven by the high costs of connectivity in the region. One respondent noted that SMS and phone calls were more likely to be used: 'they are the most direct and can get us where we want to go. If we have to go to a meeting, my friends don't always have WhatsApp, but they all have SMS'. ${ }^{5}$

The use of WhatsApp amongst rural populations and amongst the rural poor is less known than text-based applications, which have generally been used to improve the provision of health and agricultural extension services in isolated areas. Mobile health applications have assisted disease prevention and surveillance, self-management and compliance (Déglise, Suggs \& Odermatt 2012). Text apps have also assisted in expanding agricultural markets and mapping climate change, and they enable policymakers to communicate more effectively with citizens and improve service delivery. Mobile phones are also responsible for high rates of financial transfers by migrants from one country to another, particularly in economically unstable zones such as Somalia and Zimbabwe (Siegel \& Fransen 2013).

There are some groups that have managed to overcome the digital divide through increased use of broadband, but only through purchasing power. This includes the village of Hogsback, located in the Amathole Mountains. Many residents of Hogsback depend on tourism for their livelihoods, in the form of guesthouses, hotels and lodges, whilst labour for these initiatives is drawn from the residents of surrounding villages. The village therefore has a labour pool of temporary residents, largely indigent and dependent on work at guesthouses, as well as a relatively well-off group of residents and business owners. The Hogsback community attracted a fair amount of attention in 1997-1998, when a series of attacks on residents exposed critical differences between the local civic association, to which many black residents belong, and the Hogsback Local Council (now the 4.See https://qz.com/africa/1206935 (accessed 28 January 2020).

5.Respondent 4, Alice, 03 May 2016
Hogsback Ratepayers Association). A bitter relationship developed between these two groups during $1998 .{ }^{6}$ Both the Hogsback Ratepayers Association and the Community Policing Forum (CPF) communicate with each other through email and WhatsApp. They found that the municipal website was generally unavailable and faulty and that the only form of communication with the municipality was through physical attendance of meetings. The CPF indicated that phone calls and SMSs 'do not always work' in Hogsback since 'we don't have a reliable signal'. Moreover, in Alice itself, the two largest NGOs in the region - World Vision and African Footprints of Hope - use their own Wi-Fi and broadband to communicate, and this enables them to be relatively independent from the problems associated with cellular networks.

The problems associated with Internet coverage and cellular networks in Nkonkobe have certainly prevented open access to the municipal webpage - a site that is supposed to post relevant events and council meetings, engage with citizens about service delivery and offer residents a free app to check service bills and water usage. Many respondents who had access to broadband complained that this site was hardly functional and that it mostly did not work.

The problems associated with cellular networks and access to broadband can only address poverty alleviation once the problems of poor connectivity and high data charges are solved. Furthermore, there is no guarantee that people will access smartphone communication, particularly because this technology may end up favouring middle- and upper-class individuals. Rural women tend to be excluded because of their restricted mobility and lack of education, even with a regular income, and in some cases, because of male control over information and media. As this research has shown, older women tend to own regular cell phones that do not have prime Internet connectivity, and therefore they rely more on word of mouth and standard phone calls or SMS to communicate.

\section{Communication with local government stakeholders}

It is clear from the information about mobile communication in Nkonkobe thus far that there is a divide between users, based on income, gender, age and overall connectivity. Good connectivity is achieved through broadband and Wi-Fi, and it is generally available to all middle-income end users, which in Nkonkobe unfortunately excludes the majority of residents. Although cellular networks are well established in the Eastern Cape, these are not reliable, and airtime is expensive. In general, despite the widespread use and acceptance of cellular phones and smartphones in Nkonkobe, rural residents have still not completely overcome their differences with urban centres and middle-income earners, although connectivity with regional towns has definitely increased. 
However, this does not mean that rural residents in Nkonkobe are isolated. On the contrary, they are well connected and informed and certainly not disengaged from national affairs and international news. Although smartphones are important, rural residents prefer to communicate through more conventional means. From the responses to questions about which devices they most used to access information, we isolated six different types, including TVs, radios, cell phones, newspapers, computers or physical (face-to-face) meetings. The inclusion of the latter was necessary because (as suggested by group information), it seems that a primary source of municipal or council information for some individuals in rural areas are ward councillors and associated groups such as CPFs and community development forums. All of these are supposed to meet on a regular basis in each ward. Figure 3 summarises information on local government and service delivery. With regard to local government (council matters such as meetings or presentations), the use of newspapers and ward meetings featured prominently as the primary means of accessing council information. A total of $36 \%$ of people used ward meetings, and another $46.7 \%$ used newspapers. In connection to actual service delivery issues (e.g. monthly rates or upgrades), ward meetings were still by far the most popular means of accessing this type of information. Almost $57 \%$ of people preferred going to ward meetings. This outstripped devices such as radio (25.8\%) and newspapers $(17.5 \%)$.

As indicated by Figure 3, if respondents wanted to access international news items, the most popular device used was television $-63 \%$ indicated their use of TV. This outnumbered newspapers (25.2\%) and cell phones (23.7\%). With regard to jobs, $48.7 \%$ of our respondents used newspapers to peruse local opportunities. This was by far the most used medium for jobs, but it was followed closely by the use of cell phones (35.3\%) and radio $(23.5 \%)$. Issues relating to land - including cattle sales or agriculture - were marked by the relatively equal use of newspapers (32.8\%) and radio (35.3\%) to access information.

In order of popularity, ward meetings feature prominently in the search for information related to service delivery (57\%), local council matters (39\%) and education (24\%). The use of PCs is very low; they really cannot be recommended as a source of information, except for a very few. Newspapers are most popularly used to extract information relating to jobs $(49 \%)$, local council matters $(47 \%)$ and land (or

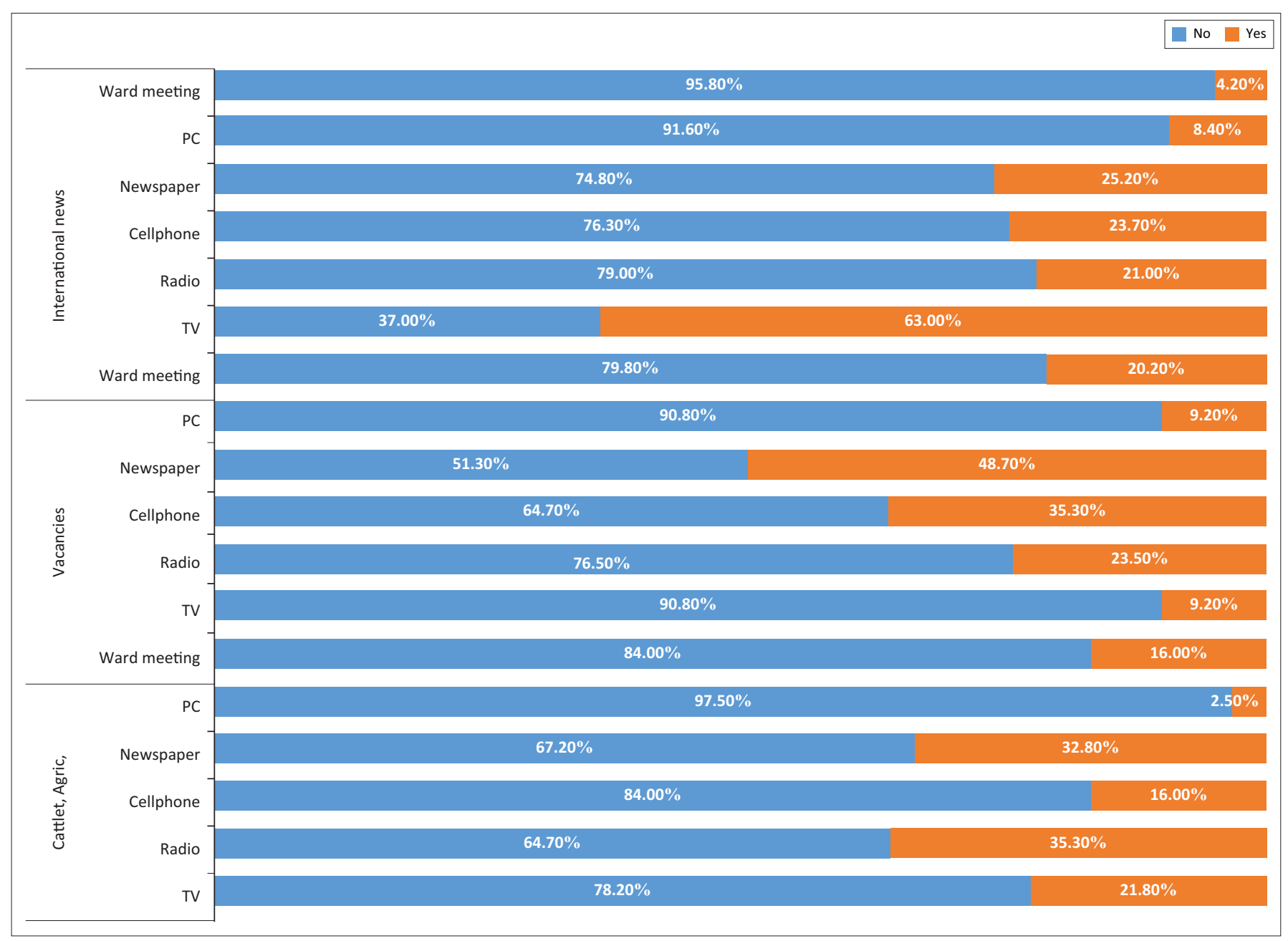

Source: Nkonkobe Local Municipality, 2011, 'Integrated Development Plan 2012-2017', Government Printers, Nkonkobe. PC, personal computer; TV, television; CATTLET, AGRIC; agricultural matters.

FIGURE 3: Devices used to access information on international news, jobs and land. 
agricultural issues, 33\%). Cell phones are used mostly for information relating to education (37\%), jobs (35\%) and international news (24\%), although the latter is on an equal par in relation to local council matters and crime. Radios feature primarily in the access to information relating to crime (40\%), land (35\%) and education (33\%). Televisions are mostly used for watching international news (63\%), and this far outstrips information relating to crime or education.

Within certain age brackets, information from the survey confirmed that the need for communication and the use of technology for communication peaks amongst people aged between 20 and 40 years. Older people as well as very young individuals do not seem to have as much need for information consumption. Television is the most popular medium for accessing information related to all the above categories. The use of cell phones for communication and information is particularly popular for those between the ages of 20 and 30, and in fact outstrips other age groups in the use of cell phones. The use of cell phones for other age categories is placed third after the use and access of written media newspapers - which is an extremely important medium for all age groups. The same applies to radio, which often is used on a similar par with newspapers.

Notably, it seems that ward meetings are popular as a form of oral and physical communication amongst people around the 30-40 age group, as well as for those above 60. In this regard, community development workers (CDWs) in Nkonkobe have been appointed by the provincial government to communicate and liaise with residents concerning service delivery issues. These include road maintenance and access, job creation, health and community projects. The primary means of communication between CDWs and local residents takes place through phone calls, SMS and newspapers adverts. The CDW worker in Alice explained that the role of ward communication was immensely positive: 'people in rural villages depended on these committees and meetings to share information with the ward councillor about service delivery'. ${ }^{7}$

The functions of a CDW are as follows:

- to be participatory change agents who work in the communities where they live

- to help people in communities improve their own lives and change their circumstances

- to help community members to understand how they can participate in development plans, facilitate community participation in policymaking, implementation, and service delivery

- to give community members information and help to empower individuals and communities

- to support community-based projects such as small business development projects.

In summary, it is clear that people in Nkonkobe still predominantly use physical meetings and face-to-face

7.Interview with Mr Nyamezeke, Alice, February 2016. communication with political agents in rural areas in order to communicate about service delivery issues. Those people who do not have access to ward meetings seem to struggle to communicate with the municipality, as the example of Hogsback indicates. In fact, De Bruijn (2008) and Castells (1996) are correct in saying that social network supports communication - without the use of cell phones and smartphones, the work of CDWs would be almost impossible, and ward meetings would not occur.

\section{Conclusion}

Despite the evolving literature on the role and relevance of mobile phone technologies in developing countries, we still know very little regarding the effects of mobile technologies on rural populations in Africa. Theoretically, improved cellular smartphone networks could substantially reduce the reliance on physical transportation and provide a way out of poverty. However, the possibility of free and easy communication is made very difficult by high cellular costs and the slow expansion of fibre and broadband in rural areas. The downside to the use of smartphones and other mechanisms of applied information technology in isolated rural areas is that this comes at a cost - although not very high, users still have to purchase data or have access to data packages, which may be difficult in deep rural areas. For the vast majority of smartphone users, connectivity compels a movement towards regional urban centres, where data are cheaper.

This study confirms that apart from regular interaction and the consumption of information on devices such as television and radio, users of smartphones are relatively young, have proper knowledge of how to operate a smartphone and a higher level of education and employment. People who do not use smartphones are more likely to be older, use an SMS-based application for information sharing and may have less income and fewer economic opportunities than smartphone users. It is also more likely that cell phone users will spend more time following up real-time conversations, meetings and interactions. However, it is true that both smartphone and regular cell phone users still rely on old-fashioned conversation and contact and that this is particularly relevant within the political realm. The local municipality and CDWs still use physical meetings to communicate with residents, and this is definitely the preferred means of communication. Second to this, residents in Nkonkobe use newspapers and radio broadcasts to remain in contact with political role-players in the region and prefer to watch television as a form of entertainment. Smartphones are therefore only part of a much broader array of communicative devices, although users are only able to access true networks and mutual reciprocity through their devices.

Based on these findings it is doubtful that smartphone and Internet usage has contributed to the development of a true network society, as Castells (1996) originally coined. Smartphones and virtual communication do not 
form the 'nerve centre' of social interaction in Nkonkobe. Instead, old-fashioned ways of communication, including meetings and face-to-face interaction, are more appropriate to the needs of rural society in Nkonkobe. Those who do have access to Internet networks are more economically privileged and are able to use reliable Internet connections. The economic and social divides between these types of residents in Nkonkobe seem to be virtually unchanged.

The future of mobile and smartphone communication in Nkonkobe thus relies on the expansion of cheap and accessible Internet data, particularly in deep rural areas. This type of technology is already supported by the widespread use of smartphones as well as the consumption of global information via television and radio. However, content provided through Internet access should not be limited to knowledge of and from outside sources but extended to ensure that rural inhabitants have the means to speak for themselves (Cecchini \& Scott 2003:76). Locally contextualised information is more relevant to improving local services than existing consumption of information provided by an external agent. Services that can combine real-life interaction with smartphone networking are clearly best suited to rural residents, as many have a preference for communication services that are personal and direct. Cellular devices (of any kind) are clearly key to these type of interactions, as they not only encourage consumption of information but enable users to send and receive messages and thereby increase their social circle and support network.

\section{Acknowledgements Competing interests}

The author declares that she has no financial or personal relationships that may have inappropriately influenced her in writing this research article.

\section{Author's contributions}

T.C. is the sole author of this research article.

\section{Funding information}

This research received no specific grants from any funding agency in the public, commercial or not-for-profit sectors.

\section{Data availability statement}

Data sharing is not applicable to this article as no new data were created or analysed in this study.

\section{Disclaimer}

The views and opinions expressed in this article are those of the author and do not necessarily reflect the official policy or position of any affiliated agency of the author.

\section{References}

Bank, L., 2015, 'City slums, rural homesteads: Migrant culture, displaced urbanism and the citizenship of the serviced house', Journal of Southern African Studies 41(5), 1067-1081. https://doi.org/10.1080/03057070.2015.1073060

Castells, M., 1996, The rise of network society, the information age: Economy, society and culture, Blackwell, Oxford.

Cecchini, S. \& Scott, C., 2003, 'Can information and communications technology applications contribute to poverty reduction? Lessons from rural India' Information Technology for Development 10(2), 73-84. https://doi.org/10.1002/ itdj.1590100203

Chambers, R., 1994, 'The origins and practice of participatory rural appraisal', World Development 22(7), 953-969. https://doi.org/10.1016/0305-750X(94)90141-4

Church, K. \& De Oliveira, R., 2013, 'What's up with WhatsApp? Comparing mobile instant messaging behaviours with traditional SMS', in Proceedings of the 15th International Conference on Human-Computer Interaction with Mobile Devices and Services, Munich, pp. 352-361, n.d.

Connor, T., 2013, Final report: Socio economic survey and community resource audit in ward 8 of the Intsika Yethu Local Municipality, Department of Human Settlements and the Fort Hare Institute of Social and Economic Research (FHISER), East London.

Connor, T. \& Mtwana, N., 2018, 'Vestige garden production and deagrarianization in three villages in the Eastern Cape, South Africa', South African Geographical Journal 100(1), 82-103. https://doi.org/10.1080/03736245.2017.1301268

De Bruijn, M., 2008, 'The telephone has grown legs': Mobile communication and social change in the margins of African society, Inaugural Address, AfrikaStudiecentrum, Leiden.

De Bruijn, M. \& Van Dijk, R., 2012, 'Connecting and change in African societies: Examples of "ethnographies of linking" in anthropology', Anthropologica 54(1) 45-59.

Déglise, C., Suggs, L.S. \& Odermatt, P., 2012, 'Short message service (SMS) applications for disease prevention in developing countries', Journal of Medical Internet Research 14(1), 3.

Donaldson, R. \& Marais, L., 2012, Small town geographies in Africa: Experiences from South Africa and elsewhere, Nova, New York, NY.

Fort Hare Institute of Social and Economic Research (FHISER), 2011, Alice housing and development: A study conducted for the Amathole development agency, University of Fort Hare, East London.

Fort Hare Institute of Social and Economic Research (FHISER), 2017, Communication on a local level: A study conducted for the German Corporation for International Cooperation (GIZ/GTZ), University of Fort Hare, East London.

Harrison, P. \& Todes, A., 2015, 'Spatial transformation in a "loosening state": South Africa in a comparative perspective', Geoforum 61, 148-162. https://doi.org/10. 1016/j.geoforum.2015.03.003

Klaufus, C., 2012, 'The symbolic dimensions of mobility: Architecture and social status in Ecuadorian informal settlements', International Journal of Urban and Regional Planning 36(4), 689-705. https://doi.org/10.1111/j.1468-2427.2012.01122.x

Marais, L., Nel, E.L. \& Donaldson, R. (eds.), 2016, Secondary cities and development, London, Routledge.

Mishi, S., Sikhunyana, Z., Ngonyama, N. \& Sibanda, K., 2020, 'Livelihood strategies and diversification amongst the poor: Evidence from South African household surveys', The Journal for Transdisciplinary Research in Southern Africa 16(1), a726. https://doi.org/10.4102/td.v16i1.726

Mitchell, J.C., 1974, 'Social networks', Annual Review of Anthropology 3(1), 279-299. https://doi.org/10.1146/annurev.an.03.100174.001431

Nkonkobe Local Municipality, 2011, 'Integrated Development Plan 2012-2017', Government Printers, Nkonkobe.

Ramburn, H. \& Van Belle, J.P., 2011, 'Inhibitors and enablers of mobile data services use in South Africa', Communications of the IBIMA 2011, 1-11. https://www. use in South Africa, Communications of the IBIMA 2011, 1-11. https://www. Inhibitors and Enablers of Mobile_Data_Services_Use_in_South_Africa/ Inhibitors_and_Enablers_of_Mobile_Data_Services_Use_in_South_Africa/ links/54a664a40cf267bdb90843fo
Services-Use-in-South-Africa.pdf.

Rogan, M., 2018, 'Food poverty, hunger and household production in rural Eastern Cape households', Development Southern Africa 35(1), 90-104. https://doi.org/1 0.1080/0376835X.2017.1358602

Ruiters, G., 2011, The fate of the Eastern Cape: History, politics and social policy, University of KwaZulu-Natal Press, Pietermaritzbug.

Siegel, M. \& Fransen, S., 2013, 'New technologies in remittance sending: Opportunities for mobile remittances in Africa', African Journal of Science, Technology, Innovation and Development 5(5), 423-438. https://doi.org/10.1080/20421338. 2013.837287

Statistics South Africa, 2011, 'Census statistics', viewed 07 May 2020, from https:// www.statssa.gov.za/publications/P03014/P030142011.pdf.

Van Dijk, A.J., 2005, The deepening divide: Inequality in the information society, Sage, Thousand Oaks, CA.

Westaway, A., 2012, 'Rural poverty in the Eastern Cape province: Legacy of apartheid or consequence of contemporary segregationism?', Development Southern Africa 29(1), 115-125. https://doi.org/10.1080/0376835X.2012.645646 